\title{
Determinants of Economic Growth in the Kingdom of Saudi Arabia: An Application of Autoregressive Distributed Lag Model
}

\author{
Prof. Hatem Hatef Abdulkadhim Altaee ${ }^{1}$, Mohamed Khaled Al-Jafari ${ }^{2}$, Masoud Ali Khalid ${ }^{3}$ \\ ${ }^{1}$ Department of Accounting, College of Administration and Financial Sciences, Cihan University, Sulaimani, \\ Sulaimaniyah-Kurdistan Region, Iraq. Email:drhatemaltaee@gmail.com. Tel: +964-7714231853 \\ ${ }^{2}$ Department of Accounting and Finance, College of Business Administration, Prince Mohammad Bin Fahd University, \\ Al Khobar, Kingdom of Saudi Arabia. E-mail: aljafarimohamedkhaled@yahoo.com. Tel: +966-530052740 \\ ${ }^{3}$ Department of Accounting \& IT, College of Administration and Financial Sciences, Cihan University, Sulaimani, \\ Sulaimaniya-Kurdistan Region, Iraq. \\ Correspondence: Prof. Dr. Hatem Hatef Abdulkadhim Altaee, Department of Accounting, College of Administration and \\ Financial Sciences, Cihan University, Sulaimani, Sulaimaniyah-Kurdistan Region, Iraq. Tel: +964-7714231853
}

Received: November 16, 2015

Accepted: November 25, $2015 \quad$ Available online: January 4, 2016

doi:10.11114/aef.v3i1.1200

URL: http://dx.doi.org/10.11114/aef.v3i1.1200

\begin{abstract}
This paper provides an empirical analysis of the relationship between economic growth and its determinants with special focus on gross fixed capital formation, export, import, and financial development for the Kingdom of Saudi Arabia (KSA). Therefore, the study utilized an annual data from 1980 till 2014, and employed both the autoregressive distributed lag model (ARDL) and the error correction method (ECM) to investigate the long-run and the short-run parameters between the variables.

The findings suggest a positive relationship between fixed capital formation, export, in one hand and economic growth in the other hand, both in the short-run and the long-run. In contrast, the financial development variable found to have a negative effect on economic growth in the short-run, however, it turned out to be positive in the long-run. Finally, the import variable showed a negative contribution to growth in the long-run as well as in the short-run. The results are consistent with the theoretical and empirical predictions.
\end{abstract}

Keywords: Economic growth, export, import, financial development, gross fixed capital formation, autoregressive distributed lag, Kingdom of Saudi Arabia

\section{Introduction}

Economists traditionally use gross domestic product (GDP) to measure economic progress. If GDP is decreasing, the economy is suffering and the nation is losing ground. If GDP is growing, the economy is healthy and the nation is moving forward. Therefore, GDP has been used in this study to represent economic growth. Regarding the factors that affect the growth of GDP of a country, there are too many. However, this study limited itself to gross fixed capital formation, export, import, and financial development due to their utmost importance.

Empirical experience confirms that gross fixed capital formation is a key driver in economic development and economic growth. Economic theory assigned six macroeconomic roles to gross fixed capital formation through which it impacts the economy. These roles can be summarized as: increasing the production capacity; increasing domestic expenditure; lowering the production cost; increasing labor productivity through the reduction of employment; permitting production of new and high quality products; and bridging the technological gap with the advanced world which will increase the share of the country in the international trade (Beddies, 1999; Ghura \& Hadjimichael, 1996; Ghura, 1997).

Export and import have their own significance to promote the production and employment growth in the country. First, growth of export in general leads to economic growth through foreign trade multiplier effort. Second, the foreign exchange made accessible by export growth allows the importation of capital goods which, in turn, increase the production capability of the economy. Third, the volume of the competition in exports markets creation causes economies of scale and an acceleration of technical progress in production (Ribeiro Ramos, 2001). Furthermore, the 
competitiveness in the international market leads to production of innovative product and enabling the domestic producers to withstand competition in the global market. The share of different countries in the international trade shows greatly the important relationship between those variables leading to rise in exports and growth in economic activity. Accordingly, several studies support the notion that there is a strong relationship between those variables and growth of GDP, (Usman et al., 2012; Velnampy \& Achchuthan, 2013).

Financial development influences economic growth by the way in which savings become accessible and the intermediation of these savings to investment opportunities that brings the highest return. Thus, construction and development of financial institutions lead to strong positive relationship between financial intermediation and economic growth. Research scholars (Demirgüç-Kunt \& Levine, 2008; Drake, 1980; Porter, 1966; and Cameron, 1972) indicate that the overall function is to lessen information and transaction costs that hindering economic activity. However, the role played by financial development in economic growth differs among countries, depending on the level of political and economic freedoms. On the other hand, Aghion \& Howitt (2009) and Adu et al., (2013), mentioned that people allocate more for saving and hence free-up resources to investors in a country with well-motorized banking system.

The intention of this research is to study empirically the effects of some macroeconomic variables on economic growth in KSA, both in the short-run and the long-run. This study employs the ARDL-bounds testing (Autoregressive Distributed Lag Model) and the ECM approach to conduct its investigation. The rest of the paper is organized as follows: Section 2 displays a brief look of previous studies. On the other hand, section 3 explains the model, data and methodological framework. Section 4 presents the empirical results, while section 5 presents the sensitivity analysis, stability tests and their interpretations. Finally, section 6 gives the concluding remarks.

\section{Literature Review}

The roles played by various economic variables in economic growth have been long debated in the empirical economic literature. Since the publication of Adam Smith's "Wealth of Nations" in 1776 to the present era, economists contributed a lot to economic development and its determinants. However, studies on the KSA tried mostly to identify the role played by one or two factors on economic growth. Below is a brief review to some of these studies in chronological order.

Al-Yousif (2000) used ordinary least squares regressions to show how the size of the government can influence economic growth. The study revealed that if size is measured as the percentage change in government expenditure, then size is positively related to growth, but if it is measured as a ratio of government expenditure to GDP, the relationship is negative.

Tuwaijri (2001) tested the causal relationship between economic growth, in one hand, exports and government spending in the other, for the Kingdom of Saudi Arabia during the period from 1969 to 1996. Results show evidence that the Kingdom's oil exports enhanced government spending, which positively and significantly impacted economic growth. A bilateral causality between economic growth and exports was found. Furthermore, the removal of government spending strengthened the causal relationship between growth and exports. The study provided a concrete evidence of the importance of government spending on economic growth.

Al-Obaid (2004) examined the long-run relationship between total government expenditure and real gross domestic product in order to assess the validity of "Wagner's Law" (hypothesis indicates that public spending tends to rise with economic growth). The cointegration test showed a positive long-run relationship between the share of public spending in GDP and GDP per capita, consistent with Wagner's prediction.

Albatel (2005) investigated the impact of population growth in the KSA on both economic growth and savings during the period 1964-2000. Recent developments in econometrical methods are used to include: stationarity tests, multivariate cointegration tests, and dynamic OLS approach. The empirical results from Johansen test of cointegration as well as from error correction models reveal the presence of co-integrating (long-run) relationship between population and economic growth and savings. These results provide support to the argument that population and economic development should be expected to possess a long-run, rather than short-run relationship. Therefore, failure to account for such a pronounced long-run relationship between population and economic growth can lead to a serious bias and incorrect inferences.

Al-Jarrah (2005) studied the causal relationships between defense spending with total real economic growth and defense spending with non-oil real growth by using two specifications. The period studied was 1970-2003, and Johansen's cointegration procedure, VECM, and the standard Granger causality procedures were employed. The findings show the existence of bi-directional causality between economic growth and defense spending, and a unidirectional causality running from non-oil economic growth to defense spending.

Mahran (2012) empirically tested the relationship between economic growth and financial intermediation for Saudi Arabia during the period 1968 till 2010. The study utilized the autoregressive distributed lag (ARDL) methods to investigate cointegration and the associated error correction model (ECM). Despite the minimal restrictions imposed on 
the functioning of the domestic financial system with a view to "fighting terrorism", the results overwhelmingly indicate that financial intermediation has impacted negatively the long-run real GDP. These findings are attributed to two sets of factors relating to the dominance of economic activities by the public sector and the characteristics of the institutional environment surrounding the private sector, as well as to some functional and structural characteristics of the financial system that have impeded its development.

Alkhathlan (2013) examined the impact of oil production on economic growth during the period 1971-2010, using ARDL approach. The aim of this study is to determine long-run relationship between oil production and economic growth by disaggregating oil production into domestic consumption of oil in industrial sector and revenues earned from export of oil. According to the findings, oil revenue has positive impact in both the short and the long-runs. On the other hand, domestic consumption of oil in industrial sector found to have a negative impact on the real gross domestic product in both the short and the long-runs.

Samargandi et al., (2013) investigated the effect of financial development on economic growth in the context of an oil-rich economy. Therefore, they allowed for the effect of financial development to be different for the oil and non-oil sectors of the economy in the long-run. Results of the autoregressive distributed lag (ARDL) bounds test technique showed that financial development has a positive impact on the growth of the non-oil sector in Saudi Arabia. In contrast, its impact on total GDP growth found to be negative and insignificant.

Alshahrani \& Alsadiq (2014) tested the short and the long-runs effects of different types of government expenditures on economic growth in the KSA during the period from 1969-2010. Their findings indicate that while private domestic and public investments, as well as healthcare expenditure, stimulate growth in the long-run, spending in the housing sector and trade openness can also increase short-run production.

Alhowaish (2014) empirically examined the causal relationships between exports, imports, and economic growth in the KSA for the period 1968-2011. Multivariate cointegration and error-correction approaches were used. The empirical results show that the KSA followed an export-led growth path and that economic growth has a significant effect on the import growth process via export growth channels. At the same time, they found that imports have little effect on the growth of output and export in the short and long-terms.

Al Khathlan (2014) investigated the impact of foreign direct investment (FDI) inflows and economic growth in Saudi Arabia. The study covered the period 1980-2010, and used the Johansen-Juselius technique for cointegration. The empirical results indicate that FDI has a non significant positive impact on economic growth over the long-term. Furthermore, government expenditure has significant and positive impact on economic growth in the long-term. In contrast, estimates of the ECM techniques demonstrate that domestic capital and employment have a positive and significant influence on economic growth in the short-term.

Alodadi \& Benhin (2015) examined the most important non-oil determinants of growth in the KSA's economy during the period 1970-2011. They utilized the Johansen approach and the error correction model to investigate the long-run and short-run relationship between all variables. The study focused on the role of non-oil sectors, given the government's determination to reduce dependence on oil income. Variables used are exports, government spending, private and public investment, religious tourism, labor and capital as independent variables. The results indicated that all variables are important to economic growth except non-oil exports, which found to have a significant effect on economic growth. Religious tourism was found to be important to economic growth, when the economy as a whole was taken into consideration. Nonetheless, when non-oil sectors were removed, the effect of religious tourism to economic growth was increased. Finally, the study revealed that government spending improves economic growth.

\section{Data, Models and Methods}

\subsection{Data Sources}

Annual time series data covering the period from 1980 till 2014 has been utilized. The data were obtained from the World Bank, World Development Indicators 2014 (WDI).

\subsection{Autoregressive Distributed Lag (ARDL) Bound Testing Approach}

Several econometrical methods have been proposed for investigating long-run equilibrium (cointegration) among variables. However, this study utilizes the autoregressive distributed lag (ARDL) modelling approach which is initially proposed by Pesaran \& Shin (1998). The main advantage of ARDL modelling lies in its flexibility that it can be useful when the variables are of different order of integration.

The ARDL model used in this study may be expressed as:

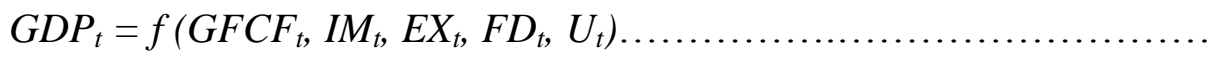


Where: GDP is the real gross domestic product, GFCF is real gross fixed capital formation, IM is real import, EX is real export, $\mathrm{FD}$ is financial development, and $\mathrm{U}$ is the error term, $\mathrm{t}$ refer to time.

The error correction version of ARDL framework pertaining to the variables included in this study and appear in equation (1) can be rewritten as follows:

$$
\begin{aligned}
& \Delta \ln G D P_{t}=\alpha_{o}+\sum_{i=1}^{n} \beta_{1} \Delta \ln G D P_{t-i}+\sum_{i=1}^{n} \beta_{2} \Delta \ln G F C F_{t-i}+\sum_{i=1}^{n} \beta_{3} \Delta \ln I M_{t-i}+\sum_{i=1}^{n} \beta_{4} \Delta \ln E X_{t-i} \\
& +\sum_{i=1}^{n} \beta_{5} \Delta \ln F D_{t-i}+\varphi_{1} \ln G D P_{t-1}+\varphi_{2} \ln G F C F_{t-1}+\varphi_{3} \ln I M_{t-1}+\varphi_{4} \ln E X_{t-1}+\varphi_{5} \ln F D_{t-1}+\varepsilon_{t} \ldots \ldots
\end{aligned}
$$

Where, the parameter $\varphi_{i}$, where $i=1,2,3,4,5$ is the corresponding long-run multipliers, whereas, the $\beta_{i}$ is parameters, where $i=1,2,3,4,5$ are the short-run dynamic coefficients of our ARDL model. $\varepsilon$ is serially uncorrelated disturbance with zero mean and constant variance, and $\Delta$ is the first difference operator.

In the next step, after confirming the long-run relationship between the variables, then the following long-run model for economic growth can be estimated:

$$
\ln G D P_{t}=\alpha_{o}+\varphi_{1} \ln G D P_{t-1}+\varphi_{2} \ln G F C F_{t-1}+\varphi_{3} \ln I M_{t-1}+\varphi_{4} \ln E X_{t-1}+\varphi_{5} \ln F D_{t-1}+\varepsilon_{t} .
$$

For selecting the appropriate lag length of the ARDL model, the researcher usually depends on the literature and the convention to determine how many lags must be used. However, there are two selections criteria that mainly used to determine the order of the ARDL model: the Schwarz Bayesian Criterion (BIC) and the Akaike Information Criterion (AIC). Given our sample size, we decided to use the BIC to determine the lag length of the ARDL model.

Finally, in order to estimate the short-run dynamics, the following error correction model was formulated:

$$
\begin{aligned}
& \Delta \ln G D P_{t}=\alpha_{o}+\sum_{i=1}^{n} b_{1} \Delta \ln G D P_{t-i}+\sum_{i=1}^{n} b_{2} \Delta \ln G F C F_{t-i}+\sum_{i=1}^{n} b_{3} \Delta \ln I M_{t-i}+\sum_{i=1}^{n} b_{4} \Delta \ln E X_{t-i} \\
& +\sum_{i=1}^{n} b_{5} \Delta \ln F D_{t-i}+\xi E C T_{t-1}+\varepsilon_{t}
\end{aligned}
$$

Where: $b_{i}, \mathrm{i}=1,2,3,4,5$ are the short-run parameters. $E C T$ is the lagged error correction term obtained from the long-run equilibrium relationship. It represents the adjustment coefficient, and should be negative, less than one and statistically significant in order to confirm the cointegration relationship.

\subsection{Unit Root Test}

As mentioned before, testing the time series data for the presence of unit roots before ARDL estimation is unnecessarily, because this estimation can accommodate any variables, which are $I(0), I(1)$, or mutually cointegrated. However, one drawback of the ARDL approach is that it cannot be estimated with $I(2)$ series. Although in this study, four of the variables (GDP, GFCF, EX, and IM) as revealed in Figure 1, are most likely to be $I(1)$.

It seems better to test them, along with the financial development series, to be sure that none of them is $I(2)$. Although, there are many tests that can be utilized to test for the stationarity of the variables. The two most popular unit root test methods are: the Augmented Dickey-Fuller (1979) test and the Phillips-Perron (1988) test which they will be will be used in this study.

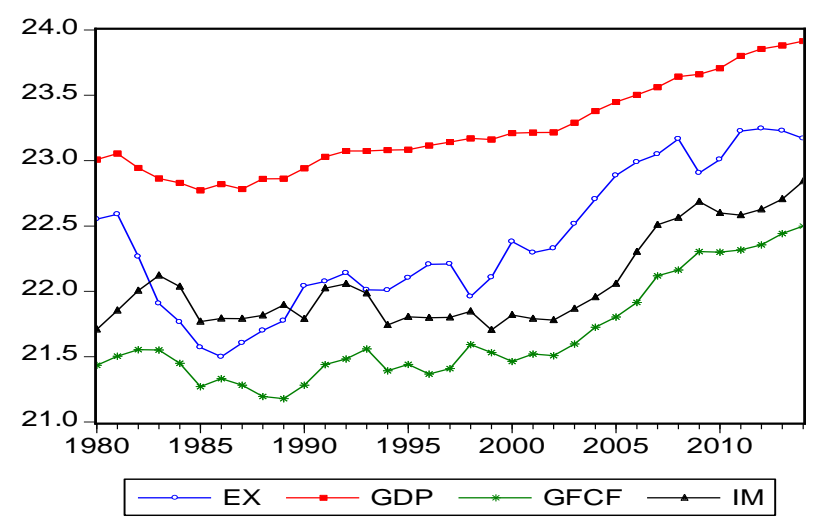

Figure 1. GDP, GFCF, EX and IM

The Augmented Dickey-Fuller (ADF) and Phillips-Perron (PP) unit root tests are presented in Table 1. Both tests suggest that, GDP, GFCF, EX, and IM variables exhibit unit roots, whereas they become stationary in the first 
differences. Furthermore, The results indicate that the financial development variable is integrated at $I(0)$. In the Augmented Dickey-Fuller (ADF) test, the gap was determined by the Akaike Information Criterion (AIC), while the Newey-West standard was utilized in the Phillips-Perron (PP) tests.

Table 1. Stationarity Tests

\begin{tabular}{|c|c|c|c|c|c|c|}
\hline \multirow[b]{2}{*}{ Variable } & \multicolumn{2}{|c|}{$\mathrm{ADF}$} & \multicolumn{2}{|r|}{ PP } & \multirow{2}{*}{ With trend } & \multirow{2}{*}{ Integration } \\
\hline & In level & In first difference & In level & In first difference & & \\
\hline GDP & -2.46321 & $-5.06241^{\text {**** }}$ & -2.46321 & $-5.17634^{* * *}$ & yes & $\mathrm{I}(1)$ \\
\hline GFCF & -1.15637 & $-5.26661^{* * *}$ & -1.20803 & $-5.25416^{* * * *}$ & yes & $\mathrm{I}(1)$ \\
\hline EX & -3.22925 & $-4.23128^{* * *}$ & -3.27674 & $-4.291439^{* * *}$ & yes & $\mathrm{I}(1)$ \\
\hline $\mathrm{IM}$ & 0.10873 & $-4.65586^{* * * *}$ & -0.06558 & $-4.64354^{* * *}$ & no & $\mathrm{I}(1)$ \\
\hline FD & $-4.76767^{* * *}$ & & $-5.47921^{* * * *}$ & & no & $\mathrm{I}(0)$ \\
\hline
\end{tabular}

Note: $* * *$ show significance at $1 \%$ level.

\subsection{Bound Tests for Cointegration}

After insuring that none of the variables is $I(2)$, then one can proceed to the next step of the ARDL analysis. In this step we examine the presence of the long-run relationships in equation 2.

F-test has been used to check the existence of a long-run relationship between the variables including following the null hypothesis i.e. $H_{O}: \varphi_{1}=\varphi_{2}=\varphi_{3}=\varphi_{4}=\varphi_{5}=0$ against the alternative hypothesis $H_{A}: \varphi_{1} \neq \varphi_{2} \neq \varphi_{3} \neq \varphi_{4} \neq \varphi_{5} \neq 0$ of cointegration, Pesaran et al., (2001). The F-test has a nonstandard distribution which depends upon: (i) whether variables included in the ARDL model are $I(0)$ or $I(1)$, (ii) the number of regressors and (iii) whether the ARDL model contains an intercept and/or a trend. The critical values are reported in Pesaran et al., (2001). If the computed F-statistics is higher than the appropriate upper bound of the critical value, the null hypothesis of no cointegration will be rejected. If it is below the appropriate lower bound, the null hypothesis cannot be rejected. If it lies within the lower and upper bounds, the result would be inconclusive. In this paper, the computed F-statistics is compared with both critical values provided by Pesaran et al., (2001).

\section{Empirical Results}

\subsection{Cointegration Tests}

Table (2) reports the results of the calculated F-statistics when each variable is considered as a dependent variable (normalized) in the ARDL-OLS regressions.

Table 2. ARDL Cointegration Tests with GDP, GFCF, EX, IM, and FD for KSA (1980-2014)

\begin{tabular}{|c|c|c|c|c|c|c|c|c|}
\hline \multirow{3}{*}{ Dependent Variable } & \multirow{3}{*}{ F-statistic } & \multicolumn{2}{|c|}{$90 \%$ Critical } & \multicolumn{2}{|c|}{$95 \%$ Critical } & \multicolumn{2}{|c|}{$99 \%$ Critical } & \multirow{3}{*}{ Outcome } \\
\hline & & \multicolumn{2}{|c|}{ Bounds } & \multicolumn{2}{|c|}{ Bounds } & \multicolumn{2}{|c|}{ Bounds } & \\
\hline & & $\mathrm{I}(0)$ & $\mathrm{I}(1)$ & $\mathrm{I}(0)$ & $\mathrm{I}(1)$ & $\mathrm{I}(0)$ & $\mathrm{I}(1)$ & \\
\hline$\overline{F_{G D P(G D P \mid G F C F, E X, I M, F D)}}$ & 4.43097 & 2.45 & 3.52 & 2.86 & 4.01 & 3.74 & 5.06 & Cointegration \\
\hline$F_{G F C F(G F C F \mid G D P, E X, I M, F D)}$ & 4.93102 & 2.45 & 3.52 & 2.86 & 4.01 & 3.74 & 5.06 & Cointegration \\
\hline$F_{E X(E X \mid G D P, G F C F, I M, F D)}$ & 2.13628 & 2.45 & 3.52 & 2.86 & 4.01 & 3.74 & 5.06 & No Cointegration \\
\hline$F_{I M(I M \mid G D P, G F C F, E X, F D)}$ & 2.57629 & 2.45 & 3.52 & 2.86 & 4.01 & 3.74 & 5.06 & No Cointegration \\
\hline$F_{F D(F D \mid G D P, G F C F, I M, E X)}$ & 3.80695 & 2.45 & 3.52 & 2.86 & 4.01 & 3.74 & 5.06 & No Cointegration \\
\hline
\end{tabular}

Note: The relevant critical value bounds are obtained from Pesaran, Shin \& Smith (2001). Table CI (iii) Case III: Unrestricted intercept and no trend p.300. The number of regressors is four.

The calculated F-statistics $F_{G D P(G D P \mid G F C F, E X, I M, F D)}=4.43097$ is higher than the upper bound critical value 4.01 at the $5 \%$ 
significant level. Also, $F_{G F C F(G F C F \mid G D P, E X, I M, F D)}=4.93102$ is higher than the upper bound test of no cointegration. Regarding the other specifications, the results show that there are no cointegration when IM, EX, and FM are used in the left hand side of our ARDL-OLS regressions. However, based on the growth theory we used GDP as the dependent variable.

\subsection{Long-Run Estimates}

The BIC selects an ARDL $(2,0,0,0,2)$ model, whose results are presented in Table (3) and Table(4). Table (3) gives the long-run coefficients of the ARDL estimations. The coefficient of gross fixed capital formation is 0.593 suggesting that GDP rises by the 0.59 percent of the increase in gross fixed capital formation in the long-run and it is significant at $1 \%$ level.

Table 3. Estimated Long-Run Coefficients Using the ARDL Approach. ARDL $(2,0,0,0,2)$ is Selected Based on Schwarz Bayesian Criterion

Dependent variable is GDP

\begin{tabular}{lccc}
\hline Regressor & Coefficient & Standard error & T-Ratio (Prob.) \\
GFCF & $0.59336^{* * *}$ & 0.103320 & $5.7429(0.000)$ \\
EX & $0.30472^{* * *}$ & 0.053848 & $5.6589(0.000)$ \\
IM & $-0.18225^{* *}$ & 0.071785 & $-2.5388(0.017)$ \\
FD & $0.27075^{* * *}$ & 0.031912 & $8.4845(0.000)$ \\
C & $6.6198^{* * *}$ & 0.612310 & $10.8113(0.000)$ \\
\hline
\end{tabular}

Note: $* * *$ show significance at $1 \%$ level, $* *$ show significance at $5 \%$ level.

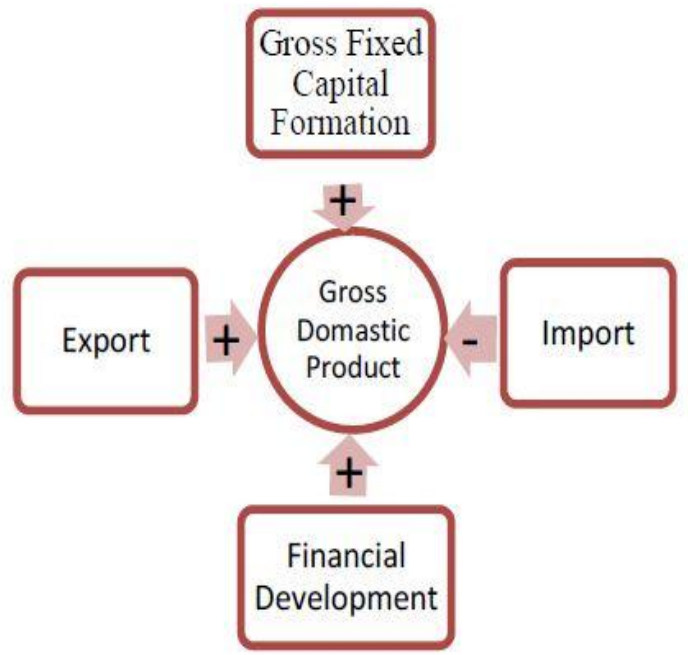

Figure 2. Long-Run Relationship

It further shows that an increase in export by 1 percent leads to 0.30 percent in the gross domestic product and it is significant at $1 \%$ level. In contrast, the long-run impact of imports on GDP is negative. This finding, although contrary to the priori expectation but it is similar to those of Paul (2014) and Islam et al., (2011). On the other hand, the coefficient of the financial development shows a significant positive impact to this variable on economic growth.

\subsection{Short-Run Dynamics}

Table (4) presents the results of the short-run parameters along with that of the error correction term. The role of gross fixed capital formation in the error-correction model remains positive and significant as before. The coefficient of export is also appropriately signed and significant at the $1 \%$ level reflecting mainly the rule of oil export in the economic growth of the KSA. 
Table 4. Error Correction Representation for the Selected ARDL Model. ARDL $(2,0,0,0,2)$ is Selected Based on Schwarz Bayesian Criterion

\begin{tabular}{|c|c|c|c|}
\hline \multicolumn{4}{|c|}{ Dependent variable is $G D P$} \\
\hline Regressor & Coefficient & Standard error & T-Ratio (Prob.) \\
\hline dGDP1 & $-0.22080^{* *}$ & 0.097515 & $-2.2642(0.032)$ \\
\hline dGFCF & $0.27099^{* * *}$ & 0.070110 & $3.8652(0.001)$ \\
\hline $\mathrm{dEX}$ & $0.13917^{* * *}$ & 0.029649 & $4.6939(0.000)$ \\
\hline dIM & $-0.083232^{* *}$ & 0.038180 & $-2.1800(0.038)$ \\
\hline $\mathrm{dFD}$ & -0.014984 & 0.042096 & $-0.35594(0.725)$ \\
\hline $\mathrm{dFD} 1$ & $-0.20879^{* * *}$ & 0.035899 & $-5.8162(0.000)$ \\
\hline $\mathrm{dC}$ & $3.0233^{* * *}$ & 0.67827 & $4.4574(0.000)$ \\
\hline $\operatorname{ECM}(-1)$ & $-0.45671^{* * *}$ & 0.075471 & $-6.0514(0.000)$ \\
\hline & & $\begin{array}{l}\text { R-Squared } \\
R \text {-Bar-Squared } \\
F \text {-stat. F(7, 27) } \\
\text { DW-statistic }\end{array}$ & $\begin{array}{l}0.87688 \\
0.83900 \\
26.4548(0.000) \\
2.5084\end{array}$ \\
\hline
\end{tabular}

$E C M=G D P-0.59336 * G F C F \quad-0.30472 * E X+0.18225 * I M-0.27075 * F D-6.6198 * \mathrm{C}$

Note: $* * *$ show significance at $1 \%$ level, ** show significance at $5 \%$ level, and * show significance at $10 \%$ level.

The above two results show that gross fixed capital formation and export can directly increase the gross domestic product. On the other hand, the coefficient of financial development turned to be negative and insignificant in the shorter period and then turned to be significant. This concurs with the argument of Lucas (1988) that the financial sector does not play an important part in real economic growth, and that the role of financial factors in economic development is often exaggerated by economists.

The error-correction term is negative as expected, and it is significant at the 1 percent level. The negative sign before the error-correction term, -0.457 , suggests that the long-run equilibrium relation comes back to the steady state if the system is ever shocked. The value of the coefficient, however, is moderate, suggesting that it will not take a long time to restore the steady-state relation if the system is disturbed.

4.4 Sensitivity Analysis and Stability Tests

The empirical estimations for autocorrelation, autoregressive conditional heteroskedasticity, normality and heteroskedasticity (sensitivity analysis) are reported in Table 5.

Table 5. Diagnostic Tests

\begin{tabular}{lll}
\hline & \multicolumn{1}{c}{ Statistics } & p-value \\
\hline A: Serial Correlation & $\mathrm{F}(1,25)=3.4940$ & 0.073 \\
B: Functional Form & $\mathrm{F}(1,25)=0.08637$ & 0.771 \\
C: Normality & $\chi^{2}(2)=2.1210$ & 0.346 \\
D: Heteroscedasticity & $\mathrm{F}(1,33)=2.3227$ & 0.137 \\
\hline
\end{tabular}

The null hypotheses are:
(A) No serial correlation.
(B) No functional form misspecification.
(C) No non-normal error.
(D) No heteroscedasticity

These results demonstrate that the short-run model passed the diagnostic tests. The results show that there is no evidence of autocorrelation at $5 \%$ confidence level and that the model passes the test for normality, the error term is also proved to be normally distributed. There is no existence of white heteroscedasticity in the model. 
For testing the stability of the long-run coefficients alone with the short-run dynamics, the cumulative sum (CUSUM) and the cumulative sum of squares (CUSUMsq) are applied. A graphical illustration of CUSUM and CUSUMsq is exposed in Figures 3 and 4. As it is obvious from Figures 1 and 2, the plots of both the CUSUM and the CUSUMsq are within the boundaries, and, hence these statistics prove the stability of the long-run coefficients of the regressors that have an effect on the economic growth in the KSA. The model appears to be stable and properly specified given that none of the two tests statistics go outside the bounds of the 5 percent level of significance.

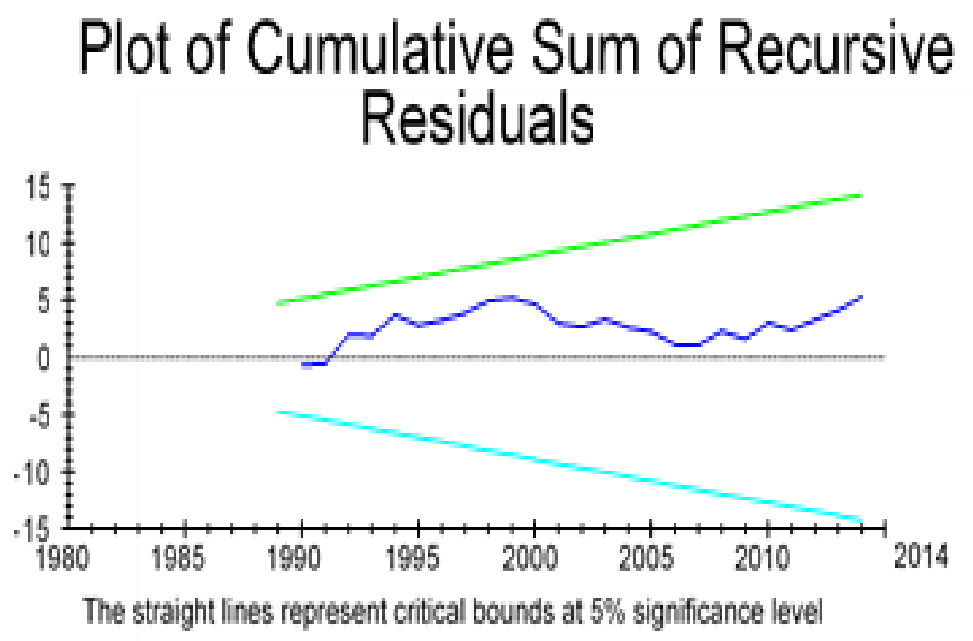

Figure 3

\section{Plot of Cumulative Sum of Squares of Recursive Residuals}

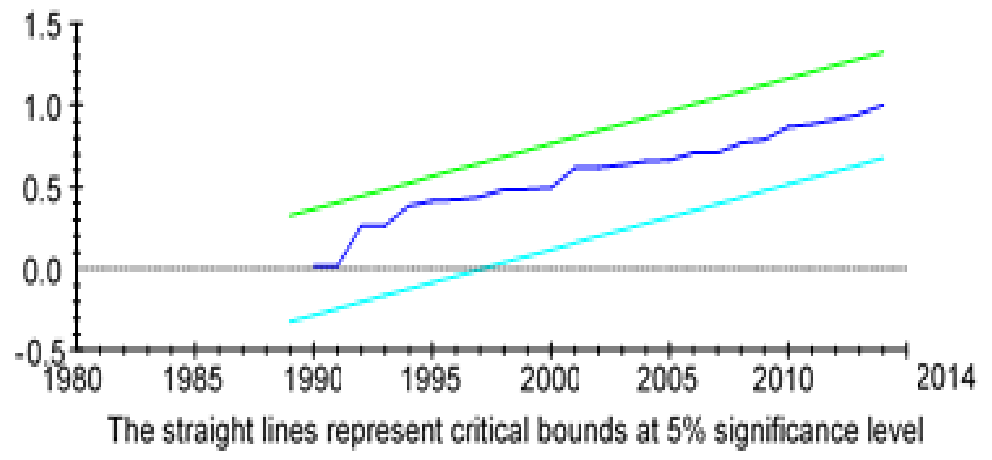

\section{Conclusion}

Figure 4

This study utilized the bounds testing (ARDL) approach to cointegration to examine the long-run and short-run relationships between gross fixed capital formation export, import, financial development and GDP growth of KSA during the period 1980-2014. The bound test suggests that the series of interests are bound together in the long-run. The associated equilibrium correction was also significant, confirming the existence of long-run relationships. The equilibrium is fairly fast and restored by almost the mid of the year.

The results also indicate, as it indicated by many other studies, that gross capital formation, export and financial development are important in explaining economic growth in the long-run in the Kingdom of Saudi Arabia. The negative import effect is consistent with previous studies. For example, Uğur, (2008) found that in the short-run import affects positively economic growth but in the long-run it affect it negatively. Moreover, Li et al., (2003) examined the effect of services import on 82 countries and found a negative impact to the import of services to economic growth in developing countries.

The diagnostic tests results of the stability of the model show that the model appears to be stable and properly specified. In addition, other results show that the estimated model is free of serial correlations, functional-form misspecification, 
non-normal errors, and heteroskedasticity.

\section{References}

Adu, G., Marbuah, G., \& Mensah, J. T. (2013). Financial development and economic growth in Ghana: Does the measure of financial development matter? Review of Development Finance, 3(4), 192-203. http://dx.doi.org/10.1016/j.rdf.2013.11.001

Aghion, P., \& Howitt, P. (2009). The Economics of Growth. MIT Press.

Albatel, A. H. (2005). Population growth and economic development in Saudi Arabia. Scientific Journal of King Faisal University (Humanities and Management Sciences), 6(2) 341-374.

Alhowaish, A. (2014). Exports, imports and economic growth in Saudi Arabia: An application of cointegration and error-correction modeling. Pensee Journal, 76(5), 120-134.

Al-Jarrah, M. A. (2005). Defense spending and economic growth in an oil-rich country: The case of Saudi Arabia. Pakistan Economic and Social Review, 43(2), 151-166.

Alkhathlan, K. (2013). Contribution of oil in economic growth of Saudi Arabia. Applied Economics Letters, 20(4), 343-348. http://dx.doi.org/10.1080/13504851.2012.703310

Al Khathlan, K. (2014). Foreign direct investment inflows and economic growth in Saudi Arabia: A co-integration analysis. Review of Economics \& Finance, 4, 70-80.

Al-Obaid, H. (2004). Rapidly changing economic environments and the Wagner's Law: The case of Saudi Arabia, Ph.D. Dissertation, (Fort Collins, Colorado: Colorado State University).

Alodadi, A., \& Benhin, J. (2015). Long term economic growth in oil-rich Saudi Arabia: What is the role for non-oil sectors? Economic Issues, 20(1), 109-129.

Alshahrani, S. A., \& Alsadiq, A. J. (2014). Economic growth and government spending in Saudi Arabia: An empirical investigation. IMF Working Paper WP/14/3.

Al-Yousif, Y. (2000). Does government expenditure inhibit or promote economic growth: Some empirical evidence from Saudi Arabia. The Indian Economic Journal, 48(2), 92-96.

Beddies, C. (1999). Investment, capital accumulation and growth: Some evidence from Gambia: 1964-1998. IMF Working Paper No. 99/117.

Cameron, R. (1972). Banking and economic development: Some lessons of history. New York: Oxford University Press.

Demirgüç-Kunt, A., \& Levine, R. (2008). Finance, financial sector policies, and long-run growth. World Bank Policy Research Working Paper No. 4469. The World Bank, Washington, DC.

Dickey, D. A., \& Fuller, W. A. (1979). Distribution of the estimators for autoregressive time series with a unit root. Journal of the American Statistical Association, 74(366), 427-431. http://dx.doi.org/10.2307/2286348

Drake, P. (1980). Money, finance and development. John Wiley, New York: Halsted Press.

Ghura, D. (1997). Private investment and endogenous growth: Evidence from Cameroon. IMF Working Paper No. $97 / 165$.

Ghura, D., \& Hadjimichael, M. T. (1996). Growth in Sub-Saharan Africa. IMF Staff Papers, 43(3), 605-634.

Islam, F., Hye, Q. M. A., \& Shahbaz, M. (2011). Imports-economic growth nexus: ARDL approach to cointegration. MPRA Paper No. 28462, http://mpra.ub.uni-muenchen.de/28462/.

Li, X., Greenway, D., \& Hine, R. C. (2003). Import of services and economic growth: A dynamic panel approach. SETI Working Paper. On line at: https://www.coleurope.eu/...servicesEUinst/.../SETI/Imports\%20of\%20se.

Lucas, R. E. (1988). On the mechanics of economic development. Journal of Monetary Economics, 22(1), 3-42. http://dx.doi.org/10.1016/0304-3932(88)90168-7

Mahran, H. A. (2012). Financial intermediation and economic growth in Saudi Arabia: An empirical analysis, 1968-2010. Modern Economy, 3, 626-640. http://dx.doi.org/10.4236/me.2012.35082

Paul, P. B. (2014). Testing export-led growth in Bangladesh: An ARDL bound test approach. International Journal of Trade, Economics and Finance, 5(1), 1-5. http://dx.doi.org/10.7763/IJTEF.2014.V5.331

Pesaran, M. H., \& Shin, Y. (1998). Generalized impulse-response analysis in linear multivariate models. Economics Letters, 58(1), 17-29. http://dx.doi.org/10.1016/S0165-1765(97)00214-0

Pesaran, M. H., Shin, Y., \& Smith, R. J. (2001). Bounds testing approaches to the analysis of level relationships. Journal 
of Applied Econometrics, 16(3), 289-326. http://dx.doi.org/10.1002/jae.616

Phillips, P. C. B., \& Perron, P. (1988). Testing for a unit root in time series regressions. Biometrika, 75(2), 335-346. http://dx.doi.org/10.1093/biomet/75.2.335

Porter, R. (1966). The promotion of banking habit and economic development. The Journal of Development Studies, 2(4), 346-366. http://dx.doi.org/10.1080/00220386608421196

Ribeiro Ramos, F. R. (2001). Export, import, and economic growth in Portugal: Evidence from causality and cointegration analysis. Economic Modelling, 18(4), 613-623. http://dx.doi.org/10.1016/S0264-9993(00)00055-9

Samargandi, N., Fidrmuc, J., \& Ghosh, S. (2013). Financial development and economic growth in an oil-rich economy: The case of Saudi Arabia. Economics and Finance Working Paper Series. Working Paper No. 13-12, Brunel University.

Tuwaijri, A. (2001). The relationship between exports and economic growth. Journal of King Saud University, 13(1), 219-234.

Uğur, A. (2008). Import and economic growth in Turkey: Evidence from multivariate VAR analysis. Journal of Economics and Business, 11(1-2), 54-75.

Usman M., Ashfaq, S., \& Mushtaq, N. (2012). Relationship of export and Growth: An empirical study of Pakistan. Far East Journal of Psychology and Business, 6(3), 1-10.

Velnampy T., \& Achchuthan, S. (2013). Export, import and economic growth: Evidence from Sri Lanka. Journal of Economics and Sustainable Development, 4(9), 147-155.

World Development Indicators (2014). The World Bank. WDI worldbank.org/ http://www.worldbank.org

\section{(cc) $\mathrm{BY}$}

This work is licensed under a Creative Commons Attribution 3.0 License. 